STUDIA POLONIJNE

T. 36. Lublin 2015

DOI: http://dx.doi.org/10.18290/sp.2015.3

MAREK GRYGIEL

\title{
POLONIA I DUSZPASTERSTWO POLONIJNE W PÓŁNOCNEJ KALIFORNII W ŚWIETLE DZIAŁALNOŚCI JANA KOWALIKA
}

Lata emigracyjne Jan Kowalik spędził w północnej Kalifornii ${ }^{1}$. To tutaj stworzył swój warsztat pracy, z tego miejsca publikował swoje najważniejsze prace bibliograficzne, prowadził szereg badań naukowych na podstawie materiałów znajdujących się w pobliskich archiwach i bibliotekach. Nawiązywał kontakty z naukowcami ze znanych kalifornijskich uniwersytetów. Kalifornia z całym swym bogactwem kulturowym i przyrodniczym stała się dla niego drugim domem, który bardzo często opisywał w swojej poezji i opowiadaniach.

Ks. dr MAReK GRYgiel SChr - adiunkt Katedry Historii Kościoła w Czasach Najnowszych, Metodologii i Nauk Pomocniczych, Instytut Historii Kościoła i Patrologii Katolickiego Uniwersytetu Lubelskiego Jana Pawła II; e-mail: marekgrygiel@yahoo.pl

${ }^{1}$ Jan Kowalik urodził się 28 sierpnia 1910 r. w Skoczowie, w powiecie cieszyńskim (Śląsk Cieszyński). Jego prawdziwe nazwisko: Jan Franciszek Slawiczek. Obok pseudonimu Kowalik używał w latach czterdziestych. dwóch innych: Jan Franciszek Suchy i Jan Pokrzywa. Kształcił się w seminarium nauczycielskim, najpierw w Cieszynie, a następnie w Bielsku-Białej (Wyższe Kursy Nauczycielskie). W 1931 r. podjął pracę jako nauczyciel. Studiował zaocznie na Uniwersytecie Jagiellońskim (historię i prawo). Zaczął wtedy pisać sporo na tematy ludoznawczo-regionalne, ogłaszając swe prace w czasopismach pedagogicznych oraz w „Zaraniu Śląskim”. Po wybuchu wojny działał w konspiracji, od 1941 r. na terytorium Generalnego Gubernatorstwa. Aresztowany w 1944 r., został wywieziony do Niemiec i osadzony w obozie we Wrexen. Po wyzwoleniu pracował przez rok jako nauczyciel w obozie dla uchodźców w Landau-Waldeck. Kolejne trzy lata spędził w sanatorium dla chorych na gruźlicę w Steinatal; najpierw jako pacjent, a potem jako administrator. Jednocześnie uczył w tamtejszej przyszpitalnej szkole. Był także komendantem obozu dla dipisów (DPs) w Landau, a następnie pracował w głównym archiwum Sekcji Obozów Koncentracyjnych w Międzynarodowej Komisji Poszukiwań (ITS) w Arolsen. W tamtym czasie współpracował z „Kroniką” (Frankfurt nad Menem), z „Ostatnimi Wiadomościami” (Mannheim), „Słowem Katolickim” (Mona- 
Od samego początku historii polskiej emigracji losy emigrantów były nieodzownie połączone z opieką duszpasterską, jaką sprawował nad nimi polski kapłan. A parafia etniczna była swego rodzaju zwornikiem polskości i skupiała wokół bogactwo form organizacyjnych ${ }^{2}$. Dlatego badanie dziejów Jana Kowalika bez zaznajomienia się z historią polskiej diaspory nad Zatoką San Francisco i jej etnicznego duszpasterstwa nie dałoby $\mathrm{z}$ pewnością pełnego obrazu jego aktywności polonijnej.

Kowalik, młody emigrant przybywający do Kalifornii, spotkał się już z dobrze zorganizowaną strukturą polonijnych organizacji.

Polacy zaczęli przybywać nad Zatokę San Francisco w latach czterdziestych XIX wieku, jedni drogą morską z Europy, inni poprzez kontynent ze wschodu Ameryki lub poprzez Cieśninę Panamską ${ }^{3}$. Byli to żołnierze walk o niepodległość Polski, często poszukiwacze złota lub podróżni szukający przygód po świecie. Mieli zawodowe wykształcenie i często znali obce języki. Ich pionierska działalność - jak później wykazał Jan Kowalik ${ }^{4}$ - zaznaczyła się na wielu polach

chium), „Szlakiem” (Weinheim). Założył i redagował obozowy tygodnik „Polak w Waldeck”. Ogłaszał reportaże, opowiadania oraz wiersze. Ukazały się dwa ich zbiory: Ścieżka przez Steinatal (wyd. Koło Organizacji Związku Pisarzy Polskich w Niemczech, 1947) oraz Wiatr w gałęziach (Wydawnictwo Polskiego Klubu Literackiego, Monachium 1948). W 1950 r. wyjechał do Stanów Zjednoczonych, gdzie przez dwa lata pracował jako stróż, czyściciel okien, nocny sprzątacz w kinie, zmywacz naczyń w restauracji. Przez trzy lata był zatrudniony na stanowisku asystenta w Hoover Library przy Uniwersytecie w Stanford. Potem ponownie zarabiał na utrzymanie pracą fizyczną, poświęcając wolny czas pracom bibliograficznym. Założył wtedy American-Polish Documentation Studio w Kalifornii i zajął się głównie dokumentacją historyczno-bibliograficzną polskiej diaspory, szczególną uwagę poświęcając prasie emigracyjnej. Publikował wiele, m.in. w paryskiej „Kulturze”, londyńskich „Wiadomościach” i „Oficynie Poetów”, w mannheimskich „Ostatnich Wiadomościach” oraz w polonijnej prasie amerykańskiej i kanadyjskiej („Przegląd Polski”, „Głos Polski”, „Prąd”, „Związkowiec”). W 1968 r. otrzymał nagrodę Fundacji im. A. Jurzykowskiego. Za wkład do historii, nauki i literatury polskiej prezydent rządu RP na uchodźstwie August Zalewski nadał Janowi Kowalikowi Złoty Krzyż Zasługi. W roku 1986 w Londynie prezydent Edward Raczyński odznaczył go Krzyżem Oficerskim Polonia Restituta. W listopadzie 1993 r. konsul generalny RP w Los Angeles, Jan Szewc, uhonorował Kowalika Krzyżem Oficerskim Za Zasługi dla Rzeczypospolitej Polskiej. Jan Kowalik zmarł w Stanach Zjednoczonych w lutym 2001 r. Miał 91 lat. Zob. M. GRYGIEL, Jan Kowalik jako dokumentalista i promotor kultury polskiej na emigracji, Lublin 2008, mps, s. 10-34.

${ }^{2}$ B. KoŁODZIEJ, Opieka duszpasterska nad wychodźcami polskimi do roku 1939, Poznań 2003, s. 81.

${ }^{3}$ J. Velikonja, Geograficzne rozmieszczenie Polaków w Stanach Zjednoczonych Ameryki, determinanty historyczne i wspótczesna dynamika, w: Polonia amerykańska. Przeszłość $i$ wspótczesność, red. H. Kubiak, E. Kusielewicz i T. Gromada, Wrocław [i in.] 1988, s. 83.

${ }^{4}$ Archiwum Instytutu Hoovera [dalej: HIA], materiały archiwalne dotyczące osoby Jana Kowalika znajdują się w zespole archiwalnym „Kowalik J.” w pudłach pod sygnaturami od Box no. 1 accession 93047-71.04 do Box no. 90 accession 93047-16.416/418; J. KowaliK, Polscy pionierzy w Kalifornii, San Jose 1982, [mps] HIA Box no.89 accession 93047-16.416/418. 
i stanowiła całkiem niemały wkład w amerykanizację Kalifornii ${ }^{5}$. Późniejsze ruchy emigracyjne miały charakter masowy i spowodowane były na przemian to uciskiem politycznym, to kryzysem gospodarczym w dziewiętnastowiecznej Europie $^{6}$. Powstała $w$ ten sposób „emigracja zarobkowa”, która swój punkt szczytowy osiągnęła w latach dwudziestych. To właśnie z tej emigracji wywodzi się rdzeń kalifornijskiej Polonii, zasilony masowym przypływem wysiedleńców i żołnierzy po II wojnie światowej.

Na podstawie dostępnego spisu ludności Kalifornii z 1970 r. można dokonać szczegółowej analizy, która pozwala nam uchwycić obraz społeczno-kulturowy Polaków zamieszkujących w tych czasach tereny Kalifornii ${ }^{8}$.

Liczba Amerykanów polskiego pochodzenia zamieszkujących Kalifornię wynosiła 115.584 osoby. Polonię nad Zatoką San Francisco w tamtych czasach cechował, jak na amerykańskie warunki, pewien rodzaj zasiedziałości. Przesiedlenia miały miejsce stosunkowo rzadkie i odbywały się zwykle w obrębie stanu. Niewielu Polaków opuszczało Kalifornię ${ }^{9}$. Istniał natomiast nieprzerwany do niej przypływ, często ludzi w podeszłym wieku, którzy przybywali tu ze względów zdrowotnych albo w celu połączenia się z rodziną. Liczba tych emigrantów ze wschodu kontynentu pod koniec lat sześćdziesiątych wynosiła 13 procent ogółu Polonii. Wspomnianą zasiedziałość możemy po części wytłumaczyć faktem, że Polonia kalifornijska była społeczeństwem biologicznie starym. Na 8107 badanych osób zaledwie 7 procent stanowiła młodzież do lat 24 . Wiek średni w granicach lat od 25 do 44 reprezentowany był liczbą 1944 osób. Mieszkańców w wieku około 50 lat i więcej zarejestrowano 5522, co stanowiło 68 procent. Zróżnicowanie Polonii metropolitalnych środowisk północnej Kalifornii wyrażało się stosunkiem 4259 mężczyzn na 3812 kobiet.

Zdawać by się mogło, że językiem macierzystym Polonii powinien być w przeważającej mierze język polski. W rzeczywistości było jednak inaczej, co tłumaczy się faktem, że Polonia była w swej istocie ambiwalentną strukturą społeczną: wznoszona na fundamencie odziedziczonych wartości etnicznych, podmywana była stale i przekształcana przez dynamiczne procesy społeczne

\footnotetext{
${ }^{5}$ M. Haiman, Polish Pioneers of California, Chicago 1940, s. 24-27.

${ }^{6}$ S. OsAD, Jak ksztattowała się polska dusza wychodźstwa w Ameryce, Pittsburg 1930, s. 129-132.

${ }^{7}$ Por. F. STASIAK, Polska emigracja zarobkowa w Stanach Zjednoczonych Ameryki 1865-1914, Warszawa 1985.

${ }^{8}$ U. S. Department of Commerce. 1970 Census of population. Subject Reports. National Origin and Language. Washigton, D.C., 1973.

${ }^{9}$ A. BARAn, J. JóźwIAK, Liczebność Polonii Stanów Zjednoczonych Ameryki w świetle polskich i amerykańskich źródeł oraz odmiennych metod obliczeniowych, w: Polonia amerykańska, s. 57.
} 
i kulturowe nowej ojczyzny. Na podstawie omawianych badań można wywnioskować, że z przyjściem na świat nowej generacji rozluźniła się więź wiążąca rodzinę emigranta $\mathrm{z}$ ojczyzną i fakt ten przesądzał stosunek do języka ojców ${ }^{10}$. Warto dodać, co jest widoczne na przykładzie także Kowalika, że językowe stosunki komplikowała także prywatna historia każdego emigranta. Zmuszony często do dłuższego postoju w Niemczech lub we Francji, przyjeżdżał do Kalifornii już z rodziną, często etnicznie mieszaną. Wszystko to znalazło odbicie w języku kalifornijskiej Polonii i tłumaczy jego statystyczną rozmaitość, nie mówiąc już o wpływach zaborów, w wieloetnicznej strukturze historycznej Polski ${ }^{11}$. I tak na 14.315 reprezentantów Polonii nad Zatoką San Francisco objętych spisem język polski jako język macierzysty podały 5584 osoby, język angielski - 455 osób, język jidisz - 2358.

Specyfikacja stosunków narodowościowych dla metropolii San Francisco w tamtych czasach wykazywała, że blisko połowa ludności miasta była obcego pochodzenia $^{12}$. Kwestionariusze spisowe dotyczące wykształcenia uwzględniały jedynie osoby powyżej 25 lat i objęły 5303 reprezentantów Polonii. Rejestrowały one wykształcenie elementarne, średnie i wyższe dla każdej płci osobno, notując 2961 studentów i 2342 studentki, razem 5303 osoby. Statystyka ta oczywiście nie unaocznia rodzaju, zasięgu i znaczenia kulturowego setek imigrantów starszego pokolenia z gruntownym europejskim wykształceniem, pracujących na kalifornijskich uniwersytetach w instytucjach badawczych oraz w przemyśle i handlu ${ }^{13}$.

Powyższe badania pokazują, jak bardzo zróżnicowanym środowiskiem była polska diaspora żyjąca w Kalifornii ${ }^{14}$. Emigracyjne dzieje Jana Kowalika wpisują się $\mathrm{w}$ tę rzeczywistość społeczno-kulturowej różnorodności nad Zatoką San Francisco.

\footnotetext{
${ }^{10}$ M. Gruchmanowska, Język Polonii amerykańskiej, w: Polonia amerykańska, s. 261.

${ }^{11}$ G. BABIŃSKI, Przemiany spoteczno-zawodowe Polonii amerykańskiej po II wojnie światowej, w: Polonia amerykańska, s. 123.

${ }^{12}$ H. JAhANESEn, A demographic profiele of the city, San Francisco 1972, s. 45.

${ }^{13}$ Who's Who in Polish America, red. F. Bolek, New York 1943; Register of Polish American scholars, scientists, writers and artists, red. D.S. Wandycz, New York 1969. Artykuły Jana Kowalika ogłoszone w „Migrant Echo” 2(1973), nr 4 - American Scholars, Scientists and Technicians of Polish Origin in California; 3(1974), nr 1, 2 - American Artists and writers of Polish Origin in California; 3(1974), nr 3 - American Motion Picture Artists, Producers, Composers and Conductors of Polish Origin in California; 4(1975), nr 1-3 - American Writers, Publicists and Journalists of Polish Origin in California.

${ }^{14}$ K. GronIOwSKI, Struktura społeczno-zawodowa Polonii amerykańskiej, w: Polonia amerykańska, s.110.
} 
Polskim emigrantom, którzy opuszczali swój ojczysty kraj i osiedlali się w nowym nieznanym świecie, towarzyszyła od samego początku potrzeba organizowania sobie życia religijnego $^{15}$. Prowadzona przez stulecia polityka represyjna zaborców ograniczająca często życie religijne doprowadziła do szczególnej sytuacji, polegającej na tym, że polskie wartości narodowe mocno sprzęgły się z elementami katolicyzmu, a sam Kościół katolicki stawał się miejscem, gdzie można było realizować ideały narodowowyzwoleńcze ${ }^{16}$. Dlatego nie dziwi fakt, że wołanie o polskich duszpasterzy, którzy mogliby zaopiekować się polskimi emigrantami, było słyszalne od samego początku polskiej emigracji. Skoncentrowanie się bowiem wokół ośrodka duszpasterskiego z polskim kapłanem wynikało nie tylko z wewnętrznej potrzeby polskich imigrantów, lecz o wiele bardziej było dla nich znakiem bezpieczeństwa i stabilizacji w nowym świecie, który od samego początku był przedłużeniem Polski i polskości na kraje osiedlenia ${ }^{17}$.

Jan Kowalik wychowany w rodzinie katolickiej na styku dwóch przenikających się wyznań ${ }^{18}$, od samego początku swej emigracyjnej tułaczki, w Kościele katolickim znajdował oparcie, a tematyka religijna bardzo często stawała się przedmiotem jego poetyckich rozważań. Dlatego bez trudności odnalazł się $\mathrm{w}$ wielowyznaniowym społeczeństwie, jakie funkcjonowało w Stanach Zjednoczonych $^{19}$.

Warto zwrócić uwagę, że Polonia w północnej Kalifornii składała się w tamtych czasach z dwu głównych ugrupowań religijnych: wyznawców Kościoła katolickiego oraz wyznawców religii mojżeszowej.

Historia Kościoła katolickiego w północnej Kalifornii notowała ponad dwadzieścia personalnych czy terytorialnych parafii etnicznych powstałych na terenie San Francisco, Oakland i San Jose w latach 1856-1921 ${ }^{20}$. Niestety, wśród nich ciągle brakowało kościoła z polskim duszpasterzem. Spowodowane to było najprawdopodobniej stosunkowo małą liczbą katolików polskiego pochodzenia na danym terenie. Ich rozproszenie na danym obszarze także nie sprzyjało spoistości polskiej grupy. Jednak faktem jest również, że ci sami prawie ludzie w tych samych warunkach diaspory zorganizowali ponad 45 społeczno-kulturalnych

\footnotetext{
${ }^{15}$ B. LEŚ, Życie religijne Polonii amerykańskiej, w: Polonia amerykańska, s. 325.

${ }^{16}$ Por. J. Walkusz, Kościót $w$ dziejach Polonii. Zagadnienia wybrane, w: W kręgu dziejów Kościoła i rodziny franciszkańskiej, red. R. Prejs, Warszawa 1999, s. 305.

${ }^{17}$ Tamże.

${ }^{18}$ W Skoczowie, rodzinnym mieście Kowalika, część ludności była wyznania protestanckiego. J. Kuś, Szkice z dziejów kościelnych Śląska Cieszyńskiego, Kraków 1983, s. 64.

${ }^{19}$ B. KoŁODZIEJ, Opieka duszpasterska, s. 10.

${ }^{20}$ J. BuRns, A History of the Archdiocese of San Francisco, vol. I, Strasbourg 1999, s. 124.
} 
organizacji o etnicznym charakterze ${ }^{21}$. Należy więc wnioskować, że kalifornijskim Polakom w tamtych czasach zależało więcej na obronie zagrożonej polskości i czynieniu pomocy dla zniewolonej ojczyzny, niż na budowie kościoła i organizowaniu polskiej parafii ${ }^{22}$.

Przez jakiś czas, na krótko przed wybuchem I wojny światowej, idea stworzenia nad Zatoką San Francisco polskiej parafii zdawała się być blisko urzeczywistnienia: ks. Jan Kanty Rozmus, gorliwy kapłan i wybitny społecznik, zdołał zabrać sumę kilku tysięcy dolarów na ten cel, lecz przedwczesna śmierć przerwała jego zbożny zamiar. Społeczność polska zużyła zebraną sumę na zakup Domu Polskiego $^{23}$ w San Francisco. Chociaż odczuwalny był brak stałej opieki duszpasterskiej ze strony amerykańskiej hierarchii kościelnej, Polonia korzystała sporadycznie z posług religijnych kleru zakonnego oraz parafialnego polskiego pochodzenia lub władającego łamaną polszczyzną. Wzmianki o tym znajdujemy w monografii o jezuitach w San Francisco ${ }^{24}$, gdzie mowa jest o księżach Stanisławie Kusiackim SJ i Józefie Guidi SJ, wezwanych w 1894 r. przez abp. J.S. Alemany'ego w celu zaopiekowania się polskimi katolikami w Dolinie Krzemowej.

Bardzo czynnym wśród Słowian nad Zatoką był przede wszystkim włoski jezuita Henryk Bontempo, który przybył do metropolii w roku 1902 i gorliwie rozpoczął działalność misyjną, ukoronowaną stworzeniem wspólnej dla wszystkich Słowian parafii i zbudowaniem kościoła Nativity przy ulicy Gougha i Franklina. Jest to ta sama świątynia, która potem przez wiele lat służyła polskim emigrantom przybyłym nad Pacyfik po II wojnie światowej ${ }^{25}$.

Bardzo często improwizowany charakter duszpasterstwa polonijnego nie był oczywiście wystarczający, toteż sytuacja musiała ulec zmianie, kiedy po zakończeniu wojny dziesiątki tysięcy nowych imigrantów nieznających języka angielskiego zaczęły napływać do Kalifornii ${ }^{26}$.

W tym samym czasie w Niemczech znajdowała się grupa około tysiąca polskich księży uwolnionych przez armię gen. Pattona $z$ hitlerowskich obozów koncentracyjnych. Wielu z nich cudownie ocalałych odmówiło powrotu do kraju $\mathrm{z}$ obawy przed kolejnym terrorem, tym razem rosyjskiego totalitaryzmu.

\footnotetext{
${ }^{21}$ K. GRUDZIŃSKI, Polacy na szerokim świecie, Warszawa 1936, s. 7.

${ }^{22}$ J. JASINSKI, Racja bytu parafii polonijnych, Pittsburg 1946, s. 23-24.

${ }^{23}$ The Hundredth Anniversary of Polish Society of California, 1863-1963, Berkeley 1963, s. 30.

${ }^{24}$ J.B. McGloIn, Jesuits by the Golden Gate. The Society of Jesus in San Francisco, 1849-1969, San Francisco 1972, s.181.

${ }^{25}$ Tamże, s. 182.

${ }^{26}$ Cz. KAMIŃSKI, Duszpasterstwo na emigracji, w: Księga tysiąclecia katolicyzmu w Polsce, red. M. Rechowicz, cz.1, Lublin 1969, s. 639-665.
} 
Dzięki akcji abp. Józefa Gawliny, któremu Stolica Apostolska powierzyła opiekę duchową nad setkami tysięcy uchodźców znajdujących się w rozproszeniu na całym świecie, episkopaty niektórych krajów wyraziły gotowość udzielenia gościnności i przyjęcia polskich księży do swoich diecezji ${ }^{27}$. Kardynał Francis Spellman z Nowego Jorku i abp John Joseph Mitty z San Francisco byli jednymi z pierwszych, którzy dali przykład rozwiązania tego problemu.

Poprzez kontakty z Polską Misją Katolicką w Niemczech, na czele której stał ks. Edward Lubowiecki, dziesięciu polskich księży z Niemiec przyjechało do archidiecezji San Francisco ${ }^{28}$. Grono to powiększyli z biegiem czasu dwaj księża profesorowie: Józef Eugeniusz Myrda - przybyły z Anglii oraz Andrzej Woźnicki, chrystusowiec (SChr) - pochodzący z Kanady. Przybysze zostali przydzieleni do diecezjalnych parafii $\mathrm{w}$ charakterze pomocników proboszczów amerykańskich, a także jako kapelani żeńskich zgromadzeń zakonnych lub kapelani szpitalni. Ich przyjazd nie zmienił wprawdzie status quo polonijnego duszpasterstwa, niemniej stanowił zapowiedź zmian na przyszłośćc ${ }^{29}$. Częściowo została zrealizowana na wiosnę 1955 r. pismem abp. Mitty skierowanym do polskich księży imigrantów ${ }^{30}$. Arcybiskup poleca duchowieństwu polskiemu w północnej Kalifornii zorganizowanie trzech ośrodków liturgicznych dla polskich imigrantów ${ }^{31}$. Dopilnowanie realizacji swych zaleceń arcybiskup Mitta powierzył ks. Bernardowi Croninowi. Według zaleceń polscy księża mieli zwoływać do wymienionych ośrodków wszystkich nowo przybyłych polskich katolików na miesięczne zgromadzenia, na których miały się odbywać nabożeństwa z kazaniami w języku polskim, modlitwy w intencji ojczyzny i adoracje przed Najświętszym Sakramentem. Obecni mogli przy tej okazji korzystać także z sakramentu pokuty. Jednakże do Komunii św., w myśl zalecenia arcybiskupa, mieli przystępować w swoich parafiach miejsca zamieszkania. Polecenie to, jak również fakt wykluczenia z programu tych zgromadzeń mszy św., każą przy-

\footnotetext{
${ }^{27}$ B. KoŁodZIEJ, Opieka duszpasterska, s. 81-83.

${ }^{28}$ Byli wśród nich księża: Witalis Banasiewicz, Antoni Dahlmana, Wojciech Głuszek, Paweł Guttman, Stefan Kopania, Wincenty Kruk, Albin Kudziełka, Henryk Maciejewski, Jan Stasiak, Franciszek Wajda.

${ }^{29}$ Polish Americans in California 1827-1977 and who's who, red. J. Przygoda, Los Angeles 1978, s. 234.

${ }^{30}$ Pismo arcybiskupa San Francisco J. Mitty do polskich księży z 10 marca 1955. Kopia w HIA Box no. 82 accession 93047-16.416/418.

${ }^{31}$ Przy kościele Nativity w San Francisco pod kierownictwem ks. F. Wajdy i W. Kruka; przy kościele St. Columba w Oakland pod kierownictwem ks. L. Degnera i ks. J. Stasiaka; przy kościele St. Anthony Church w Redwood City pod kierownictwem ks. S. Kopani i ks. Z. Dobkowskiego.
} 
puszczać, że nie chodziło tu o stworzenie namiastki parafii etnicznej, a tylko miał to być rodzaj przejściowego punktu przed ostateczną inkulturacją ze środowiskiem amerykańskiej parafii miejsca zamieszkania ${ }^{32}$.

Śledząc lokalne prasowe publikacje datowane na lata 1951-1954, można dojść do przekonania, że mimo tak miał to być pozornej formy opieki duszpasterskiej nad imigrantami z Polski na terenie metropolii San Francisco, nastąpiło wzmożenie przejawów życia religijno-społecznego ${ }^{33}$. Z biegiem czasu administracja i program tej akcji uległy terenowym i personalnym zmianom, w wyniku czego pozostały tylko ośrodki w San Francisco i Oakland ${ }^{34}$.

W San Francisco po odejściu ks. Kruszki do Oakland duszpasterzem Polonii został ks. Franciszek Wajda. Kapłan ten zdobył sobie wdzięczność i głęboki szacunek Polonii głównie za opiekę i pomoc materialną, których nigdy nie skąpił nowo przybyłym. Jan Kowalik wielokrotnie spotykał się z ks. Wajdą, często po zakończonym nabożeństwie zostawał u niego na wielogodzinne rozmowy dotyczące swoich bibliograficznych pasji. W pamiętniku pod datą 27 czerwca 1970 r. zapisał: „Spotkałem dziś na spacerze ks. Wajdę, jak zwykle życzliwy i pełen wysokiej kultury kapłan, rozmawialiśmy ponad godzinę o tym co zrobić, aby naszą trzódkę Polaków znad zatoki jeszcze bardziej zespolić”. Śmierć tego duszpasterza wywołała nie tylko głęboki żal wśród parafian, ale także wzruszający oddźwięk w prasie amerykańskiej ${ }^{35}$.

Kolejnym duszpasterzem Polaków został ks. Zygmunt Dobkowski. Za ustną jedynie aprobatą władz archidiecezji przeniósł on punkt zborny polskich parafian do kaplicy zakonu sercanek na Lonely Hill i zaprowadził tam regularne nabożeństwa i msze św. w języku angielskim z polskim kazaniem. Przechodząc po dziesięciu latach tej intensywnej pracy na emeryturę zostawił po sobie pamięć energicznego, patriotycznego kapłana oraz wszechstronnego działacza społecznego, przede wszystkim zaś niezmordowanego kwestarza, który ze szczodrobliwością odpowiadał na naglące apele o pomoc płynące z ojczyzny ${ }^{36}$.

Działalność wspomnianych księży w ramach akcji duszpasterskiej poleconej przez arcybiskupa stanowi jednakże tylko fragment w ramach ogólnej ich

\footnotetext{
${ }^{32}$ J. BURNS, A History of the Archdiocese, s. 127.

${ }^{33}$ „Polak w Kalifornii” 1(1951), nr 22; „Kronika Zachodnia” 4 (1954), nr 3.

${ }^{34}$ J. Kowalik, Polonia kalifornijska, w: Polska Misja w San Francisco, red. W. Baryski, San Francisco 1981, s. 8-12.

${ }^{35}$ H. CAEN, A day in the Life, „Cronicle San Francisco” 20(1972), nr 153, s. 2.

${ }^{36} \mathrm{~W}$ latach siedemdziesiątych kwestował pośród Polonii w północnej Kalifornii na rzecz KUL-u i Zakładu dla Ociemniałych w Laskach.
} 
działalności na terenie Kalifornii. Także inni księża, nie wciągnięci bezpośrednio do tej oficjalnej akcji, z natury swego powołania opiekowali się imigrantami osiadłymi w promieniu ich normalnej parafialnej służby. Emigranci mieli nie tylko ścisłe religijne potrzeby. Przyzwyczajeni do praktyk w starym kraju oczekiwali od polskiego księdza zaangażowania w pielęgnowanie etniczno-kulturowej tradycji, często połączonej z religią nierozerwalnym węzłem. Tym bardziej że tradycja ta żyła jeszcze wśród starych imigrantów, osiadłych w Kalifornii przed I wojną światową ${ }^{37}$. Toteż, jak przewidywano, nowo przybyłych księży można było spotkać już wkrótce na najróżnorodniejszych akcjach związanych z życiem kulturalno-społecznym polonijnego środowiska. Jednych, jak ks. Myrda i ks. Woźnicki, w roli kapelanów i moderatorów towarzystw oraz instytucji, drugich, jak ks. Maciejewski i ks. Klaja, opiekujących się obozami wakacyjnymi młodzieży. Księża Guttman, Degner, Dobkowski, Przygoda i Woźnicki organizowali programy radiowe i wygłaszali pogadanki religijne. Księża Wajda i Woźnicki postanowili za namową Jana Kowalika podjąć się redagowania dwóch wydawnictw periodycznych, a mianowicie „Echa San Francisco” i „Migranta Echo". Dzielili się swoimi duszpasterskimi doświadczeniami, zasilając artykułami łamy prasy miejscowej oraz emigracyjnej w innych krajach. Wszyscy zaś bez wyjątku uczestniczyli w uroczystościach narodowokościelnych. Kowalik, nawiązując ożywioną współpracę z miejscowymi duszpasterzami polonijnymi, dzielił się z nimi swoim doświadczeniem, ale także brał czynny udział w życiu parafii. Księża Stasiak, Malak, Woźnicki i Przygoda wspomagali materialnie założone przez Kowalika w Sunnyvale $\operatorname{APDS}^{38}$.

Reasumując, nie ma chyba dziedziny życia Polonii nad Zatoką, gdzie nie znaleźlibyśmy śladów działalności imigranta-duszpasterza bez względu na to, czy praca została mu zlecona, czy też podjął się jej z poczucia ludzkiego i narodowego obowiązku.

Przypływ nowej fali imigrantów po zakończeniu II wojny światowej zmieniał w znacznym stopniu profil duchowy i gospodarczy tutejszej Polonii. Nie tracąc niczego ze swej amerykańskiej lojalności, stała się ona bardziej świadoma swych etnicznych korzeni i nabrała poczucia wartości jako współczynnika kształtującego

\footnotetext{
${ }^{37}$ T. RADZIK, Polonia w spoteczeństwie amerykańskim do 1939 roku, w: Emigracja z ziem polskich w XX wieku, drogi awansu emigrantów, red. A. Koseski, Pułtusk 1998, s. 53-63.

${ }^{38}$ Pamiętniki Jana Kowalika [dalej: PJK], 6 brulionów, 1 - obejmuje lata 1932-1938, s. 49; 2 - lata $1939-1944$, s. $50 ; 3$ - lata 1945-1952, s. 60; 4 - lata 1953-1965, s. 100, 5 - lata 19661977, s. 100; 6 - lata 1977-1999, s.150. Wszystkie bruliony są obecnie w posiadaniu autora niniejszego artykułu; PJK, z. 6, s. 8-9.
} 
amerykańską rzeczywistość. Uwidoczniło się to głównie w założeniu własnej reprezentacji społeczno-politycznej, jakim jest Kongres Polonii Amerykańskiej Wydział Północnej Kalifornii, w zorganizowaniu własnych programów radiowych, a nawet własnej instytucji bankowej: Polam Federal Credit Union w San Francisco.

Powstały także nowe organizacje społeczno-kulturalne. Ich lista jest imponująca: Polish Veterans of World War II, Koło Żołnierzy Armii Krajowej, PolskoAmerykański Klub Inżynierów, Polish American Educational Committee, Polish American Social Club in Sacramento, Polish Women Club, Polish American Club of East Bay, Polish American Club of the Peninsula, Polish Arts and Cultural Foundation ${ }^{39}$.

Wraz z liczebnym wzrostem i organizacyjnym krzepnięciem polonijnego środowiska dojrzewała potrzeba uaktywnienia życia religijnego, szczególnie tych członków Polonii, którzy z różnych względów nie mogli czy nie chcieli korzystać z przynależności do miejscowych parafii. I tutaj na arenę weszło młode zgromadzenie zakonne - Towarzystwo Chrystusowe, założone w Polsce przed II wojną światową w celu opieki nad rozproszoną po świecie polską emigracją ${ }^{40}$. Jej pierwszym wysłannikiem był młody kapłan, wspomniany już ks. Andrzej Woźnicki, przybyły z Kanady do San Francisco w 1967 r. Po objęciu stanowiska profesora filozofii w jezuickim University of San Francisco, rozpoczął nowatorską i dość wszechstronną działalność, organizując seminaria na temat etniczności, zakładając pierwsze na tym terenie ogólnosłowiańskie audycje radiowe ${ }^{41}$, a przede wszystkim wydając razem z Janem Kowalikiem dwujęzyczne wydawnictwo periodyczne „Migrant Echo”, poświęcone etnicznopastoralnej tematyce ${ }^{42}$.

Po zbadaniu miejscowych warunków i dwukrotnej wizycie w San Francisco generała zakonu chrystusowców, ks. Wojciecha Kani z Polski, podczas której doszło do spotkania z abp. Josephem Th. McGuckenem, akcję przejęło społeczeństwo. Jesieną 1975 r. odbyła się konferencja przedstawicieli Kongresu Polonii Amerykańskiej - Wydziału Północnej Kalifornii z arcybiskupem, któremu przedłożono prośbę o ustanowienie parafii misyjnej dla ludności archidie-

\footnotetext{
${ }^{39}$ K. Groniowski, Struktura spoteczno-zawodowa Polonii amerykańskiej, w: Polonia amerykańska, s. 101.

${ }^{40}$ F. BERLIK, Historia Towarzystwa Chrystusowego dla Wychodźców 1932-1939, Poznań 1987; B. KoŁodziej, Dzieje Towarzystwa Chrystusowego dla Wychodźców 1939-1948, Poznań 1983.

${ }^{41}$ Central European Hour-Radio.

42 J. DASZYŃSKI, Polskie duszpasterstwo nad Zatoka San Francisco, broszura wydana jako dodatek do „Monitor San Francisco Cronicel” z 25 czerwca 1972.
} 
cezji i o powołanie na stanowisko proboszcza jednego z księży z Towarzystwa Chrystusowego. Na konferencji społeczeństwo polonijne reprezentowali: prezes KPA Wydziału Północnej Kalifornii inż. Zdzisław Zakrzewski oraz profesorowie Jerzy Lerski z San Francisco i Witold Sworakowski z Palo Alto. W dniu 29 stycznia 1976 r. odbyła się konferencja u arcybiskupa, w której z polskiej strony udział wzięli: prowincjał Towarzystwa Chrystusowego na Północną Amerykę i Kanadę, ks. Władysław Gowin z Detroit oraz księża Wojciech Baryski i Andrzej Woźnicki. W wyniku osiągniętego porozumienia abp McGucken wydał 6 lutego 1976 r. dekret, stwarzający pierwszą w tym mieście, jak i w całej północnej Kalifornii, polską parafię misyjną, wyznaczając jej proboszczem ks. Wojciecha Baryskiego, którego kandydaturę wysunęły władze zgromadzenia ${ }^{43}$. Nowo mianowany proboszcz patronem parafii wybrał św. Wojciecha, biskupamęczennika i apostoła Prusaków.

Inauguracyjna Msza św. odprawiona została w sali Domu Polskiego w dniu 1 lutego 1976 r. z udziałem ks. prowincjała Władysława Gowina, księży chrystusowców: Berlika i Woźnickiego, oraz emerytowanego kapelana, ks. Zygmunta Dobkowskiego ${ }^{44}$.

Zaangażowanie w życie polskiej parafii w San Francisco stanowiło dla Kowalika rodzaj specjalnej misji, którą wypełniał do końca życia. Od samego początku stał się kronikarzem wydarzeń z życia parafii i inicjatorem wielu przedsięwzięć promujących polską kulturę. Najbardziej widoczna forma jego aktywności na tym polu to działalność wydawnicza parafii.

W kilka tygodni po założeniu przez abp. McGuckena polskiej parafii misyjnej w San Francisco, ukazał się z datą 23 kwietnia 1976 r. pierwszy numer „Gazetki Parafii Św. Wojciecha" ${ }^{\text {"4 }}$. Była to dwustronnie powielana karta papieru formatu A4, a na jej treść składały się: adres proboszcza, zawiadomienie o czasie i miejscu przyszłych nabożeństw oraz spis nazwisk osób, które podjęły się przygotowania śniadań niedzielnych na najbliższą przyszłość. Ks. Wojciech Baryski oraz Jan Kowalik jako wydawca i redaktorzy tego biuletynu dziękowali w nim także za dary w postaci naczyń liturgicznych i koszyków na zbieranie kwesty, ofiarowane nowo powstałej parafii przez rodzinę Widaków oraz Zofię Smith.

Objętość gazetki zwiększała się w następnych wydaniach, dochodząc z końcem roku do ośmiu stronic. Papier był kiepskiej jakości, zapewne jakieś magazy-

\footnotetext{
43 „Informator Towarzystwa Chrystusowego dla Polonii Zagranicznej” 3 (1976), s. 13-16.

${ }^{44}$ J. KowALIK, Polonia kalifornijska, s. 20.

45 „Gazetka Parafii Świętego Wojciecha nad Zatoką św. Franciszka”, red. ks. Wojciech Baryski SChr oraz Jan Kowalik. Archiwalne numery znajdują się w Archiwum Polskiej Misji Katolickiej w San Francisco [dalej: APMS].
} 
nowe resztówki, zdobywane własnym przemysłem wydawcy, za to bardzo kolorowy, toteż numery wyglądem przypominały wiązkę plakatów czy zaproszenia, tym bardziej że teksty pisemka urozmaicone były ilustracjami i wyszukanym liternictwem tytułów. Samo pismo odbijane było w domu Kowalików w Sunnyvale. Tematyka koncentrowała się wokół liturgii kościelnego roku, parafialnoorganizacyjnych spraw oraz polonijnego kalendarza. Specjalny kącik poświęcony był dzieciom. Edytoriał księdza proboszcza, ukazujący się pod bieżącym tytułem Rozważ w sercu swoim, rodzaj homilii dla wiernych poza zasięgiem ambony, dopełniał wachlarza tematycznego gazetki, pomyślanej jako pomoc katechetyczna, wehikuł kontaktów duszpasterskich, a także jako narzędzie propagowania nowo założonej placówki misyjnej na dalekich obszarach Kalifornii. Ten ostatni fakt tłumaczy wysoki początkowo nakład gazetki, który wynosił 900 egzemplarzy, kolportowanych przez pocztę za taryfą ulgowąa ${ }^{46}$.

W miarę jak placówka parafialna wzrastała liczbowo i terytorialnie, obserwujemy dynamiczny rozwój gazetki. Objętość jej poszerzyła się do 18 stron w roku 1977, wreszcie do 26 stronic w 1978 r. Redaktorom udało się zainteresować wydawnictwem niektórych parafian oraz członków Polonii spoza parafii, co spowodowało pojawienie się na jej szpaltach nowych piór. Rozszerzyła się w rezultacie tematyka wydawnictwa i urozmaiciła szata graficzna.

Jedną z pierwszych ochotniczek była Alicja Pomian-Pożerska Matulewicz, autorka dwu tomów wierszy wydanych przez Oficynę Poetów na Emigracji w Londynie, która oprócz częstego drukowania artykułów o wileńskiej tematyce, prowadziła w piśmie rubrykę dyskusyjną, zatytułowaną Pod rozwagę.

W maju 1977 r. redaktor Jan Kowalik rozpoczął redagowanie własnej szpalty pt. Ślady polskie nad Zatoka, poświęconą polskiej przeszłości w Kalifornii ${ }^{47}$. Od listopada tegoż roku pojawił się w miesięczniku cykl artykułów o Polskiej poezji religijnej pióra znanej pisarki Ewy Emill [Marii Skoczowskiej] ${ }^{48}$, a od lutego 1978 r. odcinkami jej powieść biblijna Legendy o chtopcu ${ }^{49}$.

Równocześnie pewnej systematyzacji uległ materiał kościelnoparafialny, który zgrupowany został na pierwszych stronicach pisma w rubrykach: Stużba liturgiczno-spoteczna, Liturgia niedzieli oraz Kalendarz parafialno-polonijny. Pojawił się nowy dział poświęcony literaturze, głównie poezji. Zmarłym członkom

\footnotetext{
${ }^{46}$ S. DRAGANOwSKI, Indeks autorów i ich prac zamieszczonych w „Gazetce Parafialnej Polskiej Misji Katolickiej Świętego Wojciecha w San Francisco” oraz „Bożym Siewie” w numerach 1-60 w latach 1976-1981, San Jose, mps w posiadaniu autora.

47 „Gazetka Parafii Świętego Wojciecha nad Zatoką św. Franciszka” nr 4-15.

${ }^{48} \mathrm{Nr}$ 6-11.

${ }^{49} \mathrm{Nr} 9-14$.
} 
kalifornijskiej Polonii Stanisław Śliwiński poświęcał biograficzną rubrykę Ze wspomnieñ $^{50}$. W roku 1978 do szeregu stałych współpracowników dołączają nowe osoby, w rezultacie czego pojawiają się nowe serie artykułów, jak i przygodne omówienia aktualnej problematyki środowiska. Ks. Andrzej Woźnicki publikował od stycznia dwie serie artykułów równocześnie, jedną pod tytułem Z filozofii życia ${ }^{51}$, drugą pod bieżącym nagłówkiem Ze szlaków świata ${ }^{52}$, w których opowiadał o swoich wyprawach wysokogórskich. Seryjnie przedrukowywany był również tekst Roku polskiego ${ }^{53}$ Zofii Kossak, nostalgią zabarwione reminiscencje folkloru starej ojczyzny. Od marca Stanisław L. Lewicki, przedwojenny dziennikarz i literat, ogłaszał w gazetce serię kontrowersyjnych felietonów kulturalnych, które pobudzały środowisko do dyskusji ${ }^{54}$. Krystyna Chciuk, znana działaczka młodzieżowa, debiutowała Kącikiem harcerskim ${ }^{55}$, zaś tajemniczy „Stary Wujcio z Pieskiem" rozpoczynał od sierpniowego numeru druk interesujących artykułów biograficzno-historycznych ${ }^{56}$.

Pismo wiele uwagi poświęcało religijno-społecznej dokumentacji środowiska. Kowalik często zamieszczał faksymile korespondencji z władzami kościelnymi. Na łamach gazetki można było znaleźć listy z podziękowaniem od dostojników kościelnych odwiedzających parafię, a więc kardynałów: Wojtyły i Rubina, krajowych oraz amerykańskich biskupów, rektora KUL-u, o. Mieczysława A. Krąpca, od gości zakonnych i przedstawicieli prasy katolickiej z kraju.

W roku 1978 miało miejsce wydarzenie, które wpłynęło na zmianę formy wydawniczej pisma i znacznie rozszerzyło możliwości publikacyjne parafii św. Wojciecha. Oto dzięki wspaniałomyślności Władysława Dalegora-Sucheckiego wydawnictwo weszło w posiadanie drukarni offsetowej, co położyło kres uciążliwemu, pokątnemu powielaniu pisma. Fakt zdobycia własnej małej drukarni pozwolił Kowalikowi na realizację z dawna pielęgnowanego marzenia: założenia popularnego, regionalnego magazynu dla rodzin katolickich. Zachęcony aprobatą proboszcza redaktor przystąpił w styczniu 1979 r. do wydawania ambitniejszego pisma, któremu dał symboliczną nazwę „Boży Siew”,57. Do powzięcia tej decyzji

\footnotetext{
${ }^{50} \mathrm{Nr} 8-11$.

${ }^{51} \mathrm{Nr} 11-14$.

${ }^{52}$ Tamże.

${ }^{53} \mathrm{Nr} 6-18$

${ }^{54} \mathrm{Nr} 7-11$.

${ }^{55} \mathrm{Nr} 8-12$.

${ }^{56} \mathrm{Nr} 8-10$.

${ }^{57}$ „Boży Siew (Gods Sowing) Miesięcznik Parafii Polskiej Świętego Wojciecha nad Zatoką San Francisco", red. ks. Wojciech Baryski, Jan Kowalik. APMS, zbiór materiałów wydawniczych do
} 
przyczynił się także fakt, że na terenie Kalifornii brak było częstotliwego i regularnie ukazującego się pisma polonijnego. W takich oto warunkach, po długich latach nieurodzaju na polonijnym rynku prasowym, „Bożemu Siewowi” przypadła rola kontynuatora tradycji polskiej prasy nad Zatoką San Francisco.

$\mathrm{Z}$ biegiem czasu zakres treści pisma zaczął się coraz bardziej różnicować. Pojawiły się nowe kolumny o charakterze świeckim, kulturalno-historycznym. Wprowadzony został miesięczny Kalendarz historyczny, redagowany przez nauczyciela Franciszka Topora ${ }^{58}$, rozszerzała się kronika Zatoki San Francisco, uzupełniając ten materiał Wiadomościami kulturalnymi.

Doszła także jedyna w prasie emigracyjnej stała rubryka Jan Paweł II $w$ filatelistyce watykańskiej $i$ światowej, redagowana przez znanego filatelistę Stanisława Draganowskiego ${ }^{59}$. Kowalik zyskiwał nowych stałych współpracowników, np. Bohdana Deresiewicza z Santa Barbara, który zasilał łamy „Bożego Siewu" artykułami o miastach polskich ${ }^{60}$. Treść ożywiała wreszcie sporadyczna szpalta humoru, stronice fraszek i satyry pióra miejscowych talentów, głównie Czesława Seyferta.

Miesięcznik regionalny, podobnie jak prasa codzienna, odzwierciedla życie środowiska, jest echem wydarzeń i problematyki, które interesują, wzruszają, jednoczą lub dzielą. Jest więc rzeczą naturalną, szczególnie w warunkach, jakie istniały nad Zatoką San Francisco, że na łamach „Bożego Siewu” odnaleźć można ślady nieporozumień i sporów, jakie istniały wśród Polonii. Dyskusje tego rodzaju publikowane na łamach pisma miały charakter defensywny. Chodziło w nich najczęściej o sprecyzowanie stanowiska i roli Kościoła i parafii w życiu polskiej społeczności emigracyjnej i sprostowanie mylnych poglądów dotyczących prerogatyw katolickiego Kościoła z jednej, a uprawnień i statusu polskich organizacji społeczno-politycznych z drugiej strony. Rozsądny i zrównoważony głos zabierali w tych sprawach najczęściej Maciej Siekierski, Alicja Matulewicz, Helena Sworakowska, Daniel Palewski i ks. Jacek Przygoda ${ }^{61}$.

Dla uzupełnienia całości można dodać, że „Boży Siew” udzielał przez jakiś czas na swych szpaltach gościny grupie najmłodszych emigrantów z Polski,

\footnotetext{
„Bożego Siewu”. Pudełka numerowane od 1 do 35; wszystkie numery archiwalne „Bożego Siewu” od stycznia 1979 do listopada 1981; Korespondencja wydawnicza redakcji.

${ }^{58}$ F. Topor, Uczestnicy o Święconce, „Boży Siew” 1(1979), nr 5, s. 4; Obchód Konstytucji 3-go Maja, nr 6, s. 5; Z dziejów Polsko-Amerykańskiego Klubu na Pótwyspie, nr 7, s. 4-5.

${ }^{59}$ S. DraganowsKi, Jan Pawet II w filatelistyce watykańskiej i światowej, „Boży Siew” 1(1979), nr 12, s. 4-5; 2(1980), nr 1-3, 6-10, 12.

${ }^{60}$ B. DeReSIEwICZ, O Krakowie, mieście królewskiej sarmacji, „Boży Siew” 1(1979), nr 7; Wroctaw, „Boży Siew” 2(1980), nr 8.

${ }^{61}$ J. BAKALARZ, Refleksje na temat polemiki nad Zatoka, Poznań 1985, mps.
} 
zanim ci nie usamodzielnili się dziennikarsko i założyli własny kwartalnik pod nazwą „Kontakty”.

„Boży Siew” spełniał wielostronne i pożyteczne zadania w środowisku kalifornijskiej Polonii. Utrzymywał więź z językiem ojczystym, ożywiał folklor i tradycje narodowe, zacieśniał kontakt $\mathrm{z}$ polską kulturą rozluźnioną latami rozłąki z ojczyzną. Chętnym i zainteresowanym stwarzał możliwości zabierania głosu i wyrażania siebie. A co może najważniejsze, to to, że dokumentował polskie życie społeczno-kulturalne w północnej Kalifornii i stanowił aktualnie cenne źródło informacji dla badacza dziejów tej diaspory.

Polska Misja Katolicka doczekała się też obszernego opracowania. Okazją była rocznica powołania na Stolicę Piotrową polskiego kardynała Karola Wojtyły. Książka przygotowywana pod red. ks. Baryskiego przy dużym współudziale Jana Kowalika nosiła tytuł Jan Pawet II - pierwszy rok pontyfikatu ${ }^{62}$ i wydrukowana została offsetem, z matryc sporządzonych przez wydawcę. Oprawiona w pó1sztywną okładkę, z ilustracjami w tekście. Podtytuł wyjaśniał, że jest to praca zbiorowa Polaków parafian zamieszkałych w rejonie Zatoki San Francisco. Nie była to jednak pierwsza inicjatywa wydawnicza dotycząca osoby i pontyfikatu Jana Pawła II, dokładne omówienie tej i innych publikacji zostało zamieszczone w kolejnym paragrafie pracy zatytułowanym Bibliograficzne polonica papieskie z terenów pótnocnej Kalifornii.

Jan Kowalik poprzez swoją aktywną działalność bez wątpienia wpisał się na stałe w krajobraz kalifornijskiej Polonii. Jego inicjatywy wydawnicze, zaangażowanie społeczne i postawa człowieka humanisty, któremu na sercu leży sprawa polska, wysuwają go na czoło tej reprezentacji narodu, której przyszło żyć poza granicami kraju. Wszechstronna działalność w obszarach Polskiej Misji Katolickiej św. Wojciecha w San Francisco jest tylko potwierdzeniem tej tezy.

\section{BIBLIOGRAFIA}

BERLIK F., Historia Towarzystwa Chrystusowego dla Wychodźców 1932-1939, Poznań 1987. BuRns J., A History of the Archdiocese of San Francisco, vol. I, Strasbourg: Editions du Signe 1999.

Emigracja z ziem polskich w XX wieku, drogi awansu emigrantów, red. A. Koseski, Pułtusk: Wyższa Szkoła Humanistyczna w Pułtusku 1998.

KoŁODZIEJ B., Opieka duszpasterska nad wychodźcami polskimi do roku 1939, Poznań 2003.

\footnotetext{
${ }^{62}$ Jan Pawet II - pierwszy rok pontyfikatu. Wydanie okazyjne przez „Boży Siew”. Staraniem Rady Parafialnej Polskiej Misji Katolickiej Świętego Wojciecha w San Francisco, San Francisco 1979.
} 
KuŚ J., Szkice z dziejów kościelnych Śląska Cieszyńskiego, Kraków: Polskie Towarzystwo Teologiczne 1983.

McGloIN J.B., Jesuits by the Golden Gate. The Society of Jesus in San Francisco 18491969, San Francisco: University of San Francisco 1972.

Polish Americans in California 1827-1977 and who's who, red. J. Przygoda, Los Angeles: Loyola Marymount University 1978.

Polonia amerykańska. Przeszłość i współczesność, red. H. Kubiak, E. Kusielewicz, T. Gromada, Wrocław: Zakład Narodowy im. Ossolińskich 1988.

Register of Polish American scholars, scientists, writers and artists, red. D.S. Wandycz, New York: The Polish Institute of Arts and Sciences in America 1969.

STASIAK F., Polska emigracja zarobkowa w Stanach Zjednoczonych Ameryki 1865-1914, Warszawa: Wydawnictwo Naukowe PWN 1985.

\title{
POLISH DIASPORA AND PASTORAL CARE IN NORTH CALIFORNIA IN THE LIGHT OF JAN KOWALIK'S ACTIVITY
}

\begin{abstract}
Su m mary
Jan Kowalik spent his emigration years in northern California, where he improved his professional skills. His life is inextricably linked with the history of the very diverse Polish diaspora over the San Francisco Bay and ethnic pastoral care. The article describes the Polish diaspora in California, which began to arrive in San Francisco Bay in the 1840s. Then, as a "labor emigration," being the core of the Polish diaspora in California, it reached its peak in the 1920s, and was powered after the Second World War. In addition, the article shows the importance of the Catholic Church and pastors, especially the Society of Christ, to migrants.

Jan Kowalik became a chronicler of parish life and launched many initiatives promoting Polish culture. The most visible form of his activity was publishing activity. As the editor of "St. Adalbert Catholic Parish Bulletin" (published since April 23, 1976), in 1977 he began publishing his own column, "Polish Traces over the Bay," dedicated to the past of Poles in California. In January 1979, he started to publish "God's Sowing." The author of the article broadly discusses both publications, pointing out their authors and editorial collaborators.
\end{abstract}

Key words: Jan Kowalik; Northern California; San Francisco; Polish diaspora; St. Adalbert Catholic Parish Bulletin; God's Sowing. 


\section{POLONIA I DUSZPASTERSTWO POLONIJNE W PÓŁNOCNEJ KALIFORNII W ŚWIETLE DZIAŁALNOŚCI JANA KOWALIKA}

\section{Streszczenie}

Emigracyjne lata swego życia Jan Kowalik spędził w północnej Kalifornii, gdzie stworzył sobie warsztat pracy. Jego losy nieodłącznie łączą się z historią bardzo zróżnicowanego środowiska polskiej diaspory nad Zatoką San Francisco oraz etnicznego duszpasterstwa. Artykuł charakteryzuje kalifornijską Polonię, która nad Zatokę San Francisco zaczęła przybywać w latach czterdziestych XIX wieku, następnie jako „emigracja zarobkowa", stanowiąca rdzeń kalifornijskiej Polonii, swój punkt szczytowy osiągnęła w latach dwudziestych XX wieku, a zasilona została po II wojnie światowej. Ponadto ukazuje rolę Kościoła katolickiego oraz duszpasterzy, zwłaszcza Towarzystwa Chrystusowego, w życiu emigrantów.

Kowalik stał się kronikarzem wydarzeń z życia parafii i inicjatorem wielu przedsięwzięć promujących polską kulturę. Najbardziej widoczną formę jego aktywności stanowi działalność wydawnicza. Jako redaktor „Gazetki Parafii Świętego Wojciecha” (ukazywała się od 23 kwietnia 1976 r.) w 1977 r. rozpoczął wydawanie własnej szpalty pt. „Ślady polskie nad Zatoką", poświęconej polskiej przeszłości w Kalifornii. Od stycznia 1979 r. wydawał „Boży Siew”. Autor artykułu szeroko omawia obie publikacje, wskazując autorów i współpracowników redakcji.

Słowa kluczowe: Jan Kowalik; północna Kalifornia; San Francisco; Polonia; „Gazetka Parafii Świętego Wojciecha”; „Boży Siew”. 
